\title{
Metal/metalloid bioavailability considerations in addressing site risk and remediation in mine closure
}

\author{
S.C. Robinson Golder Associates Inc., USA
}

\begin{abstract}
Current best mining practices call for mine closure planning throughout the lifecycle of a mining project, and many countries have specific guidance for developing mine closure plans. These guidelines (country-specific) are intended to address the footprint left behind from historical mining and processing activities and ensure that the post-closure condition does not represent a health risk to current or future communities and the environment (biodiversity). Among many other aspects, the closure plan should provide an approach for evaluating post-closure risk that incorporates the best available site data, including environmental (e.g., physical, chemical, biological, end-use and social data) - all of which are important for developing a site-specific post-closure risk assessment and protective site remediation levels. A key issue in characterising potential chemical exposure and risk from a closed mine site is understanding the chemical and physical processes affecting site environmental media (e.g., tailings, contaminated soil, surface water, etc.) as these characteristics influence chemical (metal/metalloid) mobility and bioavailability. Important fate characteristics influencing bioavailability include $\mathrm{pH}$, soil cation exchange capacity, organic carbon content, acid volatile sulphides and redox potential. Reduced bioavailability as a result of site and media-specific physical/chemical characteristics translates to a reduction in organism (human, ecological) toxicity potential and, as illustrated for human health, in the development of more-realistic (and site-specific) remediation levels. Accordingly, understanding mine site environmental conditions affecting bioavailability is important in preparing a scientifically robust mine closure risk assessment and in developing site-specific remediation levels protective of site end uses.
\end{abstract}

\section{$1 \quad$ Introduction}

Understanding the potential for exposure of local communities using a closed mine site in the future where metals/metalloids are of concern is an important part of the closure risk assessment and cleanup-level development process. Specific guidelines for assessing post-closure risk are country-specific and are not reviewed here; in many cases these guidelines are not specific to mine closure sites. However, the purpose of contaminated site guidelines is to address the footprint left behind from historical site activities (e.g., mining and processing) and to ensure that the post-closure condition does not represent a risk to current or future communities and the environment (biodiversity). Typically, contaminated site and/or mine closure guidelines (not reviewed here) provide a framework for identifying and assessing the health and environmental risk associated with the site to be closed. In some countries, including the United States, the United Kingdom and Canada, risk-based media (e.g., soil, water) concentrations developed by federal, state or provincial agencies are available for consideration as first-tier screening levels to establish whether there is a potential for site risk associated with some (but not all) post-closure use scenarios (e.g., residential, industrial). Frequently, generic soil standards are available with guidance for conducting tiered assessments, with or without consideration of bioavailability, on a site-specific basis. For large and often complex sites, which mining sites often represent, a tiered approach that includes methods for evaluating bioavailability is most scientifically defensible. In this paper, bioavailability-defined as the extent to which a substance can be absorbed by a living organism and reach systemic circulation -is discussed relative to why and when it is important to consider, the history of its use, key environmental fate factors affecting it and its use to evaluate environmentally relevant exposure and realistic remediation levels. 


\section{$2 \quad$ Why and when to consider bioavailability}

Bioavailability is an important concept to be considered in both human and ecological site risk assessments as well as in determining potential cleanup levels, where required (NRC, 2003). While consideration of the processes affecting bioavailability should be an integral part of a risk assessment and/or the development of risk-based cleanup levels, it is often neglected due to a perceived greater 'burden of proof' for incorporating bioavailability into decision making (NRC, 2003).

A key part of understanding metal/metalloid exposure at a site (for example, a smelting and/or mine site) is establishing whether and to what degree soil- and/or mineral matrix-bound metals can be absorbed into (i.e., become bioavailable) to the circulatory system of exposed terrestrial receptor groups (e.g., people, animals, plants, etc.), since it is known that total (bulk) concentrations in soil and total concentrations in water do not correlate well with toxicity (Ruby et al., 1999; Smolders et al., 2009). In aquatic environments, understanding the local water chemistry is particularly important because it strongly influences the uptake, and hence toxicity, of metals to aquatic life in fresh water.

On a site-specific basis, bioavailability is important because in many risk assessments there is a 'gap' that typically occurs between the exposure assessment step, where the metal dose is quantified, and the toxicity or effects assessment steps, where toxicity benchmarks are identified to evaluate whether a dose or concentration poses a potential risk. When discussing human health, toxicity benchmark values used are typically represented by reference doses, derived no-effect levels and cancer slope factors. Ecological toxicity is typically represented by toxicity reference values and by predicted no effect concentrations (PNECs), which address sensitive toxicological endpoints (i.e., growth, survival and reproduction) and are derived from the scientific literature. The 'gap' between the exposure and toxicity lies in the different forms of the chemical that occur in the exposure matrices at a site (e.g., soil, sediment and water) versus the form of the chemical underlying its chemical toxicity benchmark, which is used to characterise risk. The toxicity and/or carcinogenicity associated with these different forms can be quite different, but these differences may not always be accounted for in the risk assessment or in developing cleanup levels. However, where site contamination conditions warrant, considering bioavailability adjustments makes sense.

This raises the question of when does it make sense to consider bioaccessibility testing for a site. The case is strongest when there is a convergence of certain factors, specifically: (1) when the contaminant of concern for in-vitro bioaccessibility (IVBA) or other bio-elution testing is likely to be a risk and remediation driver at the site; (2) when default assumptions on bioavailability are inappropriate, based on the site exposure media; (3) where a significant change to remedial goals is likely by incorporating bioaccessibility (i.e., where large amounts of contaminated soil or waste are involved); and (4) where conditions at the site are unlikely to change substantially over time. Accordingly, it is prudent that regulators support the use of IVBA assessments at sites where respondents have an interest in conducting defensible cleanups, as well as at sites where the regulatory agency must shoulder the cost of site remediation and where significant costs in cleanup can be realised by developing site-specific cleanup levels. It is recommended therefore that where conditions at a site warrant it, as noted previously, bioavailability be considered.

To illustrate the importance of considering bioavailability, the degree of exposure and risk will be directly proportional to bioavailability such that a higher site-specific bioavailability from site exposure matrices will translate to higher receptor exposure and risk and higher remediation costs (Figure 1). Conversely, in developing risk-based cleanup levels, bioavailability is inversely proportional to the magnitude of the chemical/metal/metalloid cleanup level such that the higher the bioavailability from site matrices, the lower will be the cleanup level for that matrix and hence the greater the remediation that will be required. When differences in bioavailability between site exposure media and toxicity benchmarks are not considered, this can result in an inaccurate estimation of exposure/risk and thus inaccurate cleanup levels (if desktop-derived), which in turn can result in either too much or too little site remediation to protect health and the environment (Figure 1). 


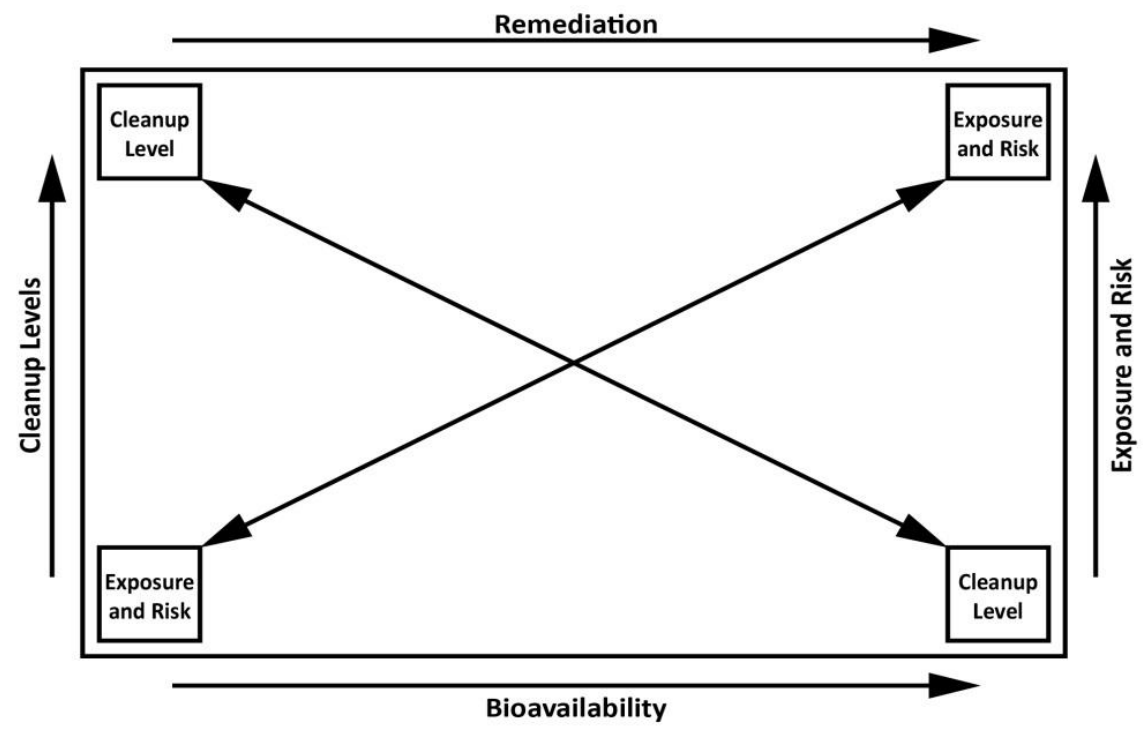

Figure 1 Relationship between bioavailability, risk, clean-up levels and remediation

\section{$3 \quad$ History and use of bioavailability in risk assessment}

First, some definitions:

- Bioavailability: The extent to which a substance can be absorbed by a living organism. Typically, this is measured using a live (in-vivo) animal study.

- Bioaccessibility: The bioaccessible fraction of a medium is the fraction that is soluble under physiological conditions and therefore potentially available for absorption into systemic circulation. Typically this is measured using a bench top laboratory test known as a physiologically based extraction test (PBET).

- Relative bioavailability: The ratio of the absorbed fraction from a site medium, such as soil or sediment, to the absorbed fraction from a reference material (often the medium in the underlying toxicity study, which is often a water-soluble metal/metalloid form).

The concepts of bioavailability and bioaccessibility and their incorporation into site-specific human health risk assessment have been employed for decades. Early work focussed on the dissolution kinetics of lead under the simulated gastric conditions typically evaluated in bioaccessibility testing (Ruby et al., 1992, 1993) though the very early bioaccessibility test precursors likely sprang from evaluations of gastric function and digestion (e.g., Malagelada et al., 1976, 1984). Over the past two decades, as the practice of risk assessment has matured there has been an increasing emphasis on incorporating relevant measures of environmental exposure to ensure that site assessments are realistic. During this period a body of literature was growing that indicated that metals/metalloids (typically lead and arsenic) are less well absorbed from soil by the gastrointestinal tract (Freeman et al., 1995; Ruby et al., 1999; Roberts et al., 2002, 2006).

As interest grew in the site-specific bioavailability to people of metals/metalloids in contaminated soils, animal soil feeding studies with lead using a number of animal models, including juvenile swine, and with arsenic in cynomolgus monkeys, began to be undertaken at some sites in the United States - typically 'Superfund' sites (e.g., Casteel et al., 1997; Freeman et al., 1995). These studies, typically live animal feeding studies, evaluated the relative bioavailability from soils from a variety of contaminated metals sites. However, there was concern among risk practitioners that the evaluation of site-specific bioavailability was cost-prohibitive due to the time and great expense associated with conducting live animal feeding studies, and also because the studies were limited in scope due to the small number of samples that could actually be tested. As additional data on lead bioavailability began to show that bioavailability varied by metal form and solubility, and with the cost of animal model testing being very expensive, alternatives to evaluating site-specific bioavailability in human health risk assessment began to develop. 
In 1996, Ruby and coauthors reported on a PBET for predicting bioavailability of lead and arsenic from a solid matrix (such as soil or mine waste) that incorporated human gastric tract parameters (Ruby et al., 1996). For lead, the model was reported to correlate well $\left(r^{2}=0.93\right)$ with the Sprague-Dawley rat model, and for arsenic the results were found to overpredict the bioavailability in rabbit and primate feeding studies by $2-11 \%$ (Ruby et al., 1996). Work on the in-vitro method for lead continued, including examining the issue of validation with animal models. In 2007, Drexler and Brattin reported on a relative bioaccessibility leaching procedure (a PBET) for estimating the in-vivo (juvenile swine) relative bioavailability of lead in solid media using an in-vitro bench-top test (Drexler and Brattin, 2007). The swine model is intended to simulate bioavailability conditions for young children.

Though other bioavailability and bioaccessibility studies continued to be conducted with lead at numerous sites, many of which were United States Environmental Protection Agency (USEPA) Superfund sites, in 2007 the USEPA released guidance for evaluating the bioavailability of metals in soils for use in human health risk assessment (USEPA, 2007b) which contains a review of the available lead bioavailability and bioaccessibility data. At the same time, the USEPA released guidance for evaluating the relative bioavailability of lead in soil using in-vivo and in-vitro methods (USEPA, 2007c). The following year, a Standard Operating Procedure for conducting the in-vitro bioaccessibility assay for lead was implemented by the USEPA (USEPA, 2008). Then, in 2009, the USEPA released a validation study of the IVBA method for lead (USEPA, 2009) that evaluated and correlated the IVBA of lead to the bioavailability measured in juvenile swine feeding studies across a wide range of lead soil and mineral phase concentrations. Strong correlations of the IVBA and live animal studies were developed in the study, which validated the premise that the IVBA method could predict reasonably well (and with low measurement error) the bioavailability of lead in juvenile swine. Correlations of the IVBA and swine bioavailability data were evaluated using three different mathematical models: a linear model $\left(R^{2}=0.92\right)$ and two different exponential models $\left(R^{2}\right.$ values of $\left.0.93,0.94\right)$.

Until very recently, the USEPA indicated that for arsenic the existing data were inadequate to demonstrate that the relative bioavailability predicted from IVBA data would be quantitatively reliable across a broad range of soil and mineral characteristics and that it did not meet the validation criteria (i.e., as established for lead) for use in arsenic risk assessment applications or as established by EPA for considering bioavailability in human health risk assessment (USEPA, 2007b). Therefore, bioavailability using live animals continued to be the practice for arsenic. Interestingly, the EPA's webpage addressing frequently asked questions on assessing relative bioavailability in soil at Superfund sites still contains the caution against the use of an in-vitro approach for assessing arsenic relative bioavailability.

Similar to lead, research including live animal and IVBA tests for arsenic has continued since the 1990s. Work on validating arsenic IVBA against live animal test data has also continued. In 2012, a final report coauthored by the USEPA (Region 8) and the consulting firm Exponent was released that provided a thorough evaluation of the available bioavailability data for arsenic and summarised the validation studies using the arsenic IVBA for soils and sediments from numerous sites where the animal testing had been completed (Griffin and Lowney, 2012). Overall, good correlations that met established validation criteria were obtained between the arsenic measured in the IVBA and the bioavailability of arsenic measured in feeding studies with swine $\left(R^{2}=0.72\right)$ and monkeys $\left(R^{2}=0.75\right)$. The overall results of the arsenic validation analysis were shown to have met required validation criteria previously applied to lead.

Peer-reviewed studies of the underlying arsenic validation work will be published in 2013. The arsenic validation study and underlying research has been presented to the USEPA's Bioavailability Subcommittee of the Technical Review Workgroup. This group is in the process of preparing a position paper recommending use of the IVBA test for arsenic nationwide. Therefore, in the US resistance to incorporating measures of oral bioaccessibility in human health risk assessment and associated risk management decision making is falling away.

Bioaccessibility and its counterpart, live animal feeding studies, are focussed on the soil ingestion pathway, which is often a driving pathway in risk assessments and remedial decision making. However, these are not the only ways to incorporate bioavailability into human health risk assessment. Though it is beyond the 
scope of this paper to identify and discuss all possible approaches, another pathway that can sometimes drive (even above ingestion exposures) is the skin contact (dermal absorption) pathway. Rhesus monkey and swine animal models have been used in conducting in-vivo dermal studies. In-vitro dermal studies, which are more cost-effective, are typically performed using human cadaver skin because no simple in-vitro extraction methods have yet been developed (or accepted by regulatory agencies) for 'routine' use in screening a series of site soils for relative dermal bioavailability. Particulate inhalation is not generally a driving pathway at contaminated sites (i.e., unless high-dust recreational vehicle use is probable), and invitro methods are not currently used to assess this pathway. However, research on developing in-vitro biomimetic (bio-elution) tests to evaluate absorption from simulated skin sweat and lung fluid is underway.

In Europe it is unclear if, or how broadly, bioaccessibility testing to support human health risk assessment is used (or accepted). For example, in a 2005 science update (UK Environment Agency, 2005) the UK Environment Agency expresses ambivalence in its use, and though they do not prohibit practitioners from using bioaccessibility, they do require submission of a strong body of scientific evidence to support use and the use of bioaccessibility methods that are scientifically robust and suitable for the site and contaminants being studied. A second science update (UK Environment Agency, 2007; post 2007) did not refute the 2005 finding but continues to highlight the uncertainties of using in-vitro methods in the United Kingdom.

For ecological evaluations, site-specific bioavailability is commonly evaluated at mine sites in the United States and internationally using a variety of approaches. Common methods include (but are not limited to):

- Evaluation of soil/sediment physical and chemical factors (nature of solids and metal associations, speciation, including Acid Volatile Sulphide in sediment).

- Measurement of labile (available) soil fractions of metal present (sequential extractions) versus total concentrations to identify bioavailable fractions.

- Evaluating site water chemistry to evaluate metal toxicity to aquatic receptors using the Biotic Ligand Model (BLM).

- Measurement of tissue concentrations at various trophic levels (receptor, prey species), which provides an integrated understanding of bioavailability incorporating multiple receptor exposure pathways and can address secondary poisoning.

- Laboratory and/or in-situ toxicity tests (terrestrial, aquatic), which also provide an assessment of integrated exposure and bioavailability.

Many of these approaches are also used in European ecological risk assessments and in implementing riskbased water quality standards, such as in the United Kingdom (UK Environment Agency, 2008a, 2008b, 2009). European ecological risk assessments also are more commonly incorporating quantitative bioavailability adjustments to ecological predicted no effect concentrations for terrestrial receptors at contaminated sites, based in large part on comprehensive chemical risk assessments conducted under current regulations, including the existing substances regulation (Council of the European Communities Regulation 793/93) and REACH (Registration, Evaluation, Authorisation and Restriction of Chemicals). Both Europe and the United States utilise the Biotic Ligand Model for evaluating bioavailability to aquatic receptors, and 'user friendly' models are available for use.

\section{$4 \quad$ Fate processes affecting bioavailability}

\subsection{Soil and sediment}

Bulk soil/sediment concentrations are typically poor predictors of toxicity to human and ecological receptors (Alexander et al., 1998; USEPA, 2007a), though this is often the form evaluated during site investigation and closure activities. Considerable research has demonstrated that systemic absorption and toxicity of metals/metalloids can be significantly reduced when site exposures are predominantly to solid forms or the metals are contained within environmental media such as soil, slag, or ore (Ruby et al., 1999; 
USEPA, 2007a, b, c; Schaider et al., 2007; Meunier et al., 2010). In porous media such as soil, the most important solids for adsorption reactions (which reduce bioavailability) are oxyhydroxides of iron and manganese (Langmuir et al., 2003). Metal adsorption capacity in soil is a function of surface area and surface site density, and the greatest site densities are those of organic material (e.g., organic carbon) and oxyhydroxides (USEPA, 2007a). Accordingly, in soil, the higher the organic carbon content and/or the oxides of iron and manganese, the lower will be metal bioavailability (Kim et al., 2003; Davis et al., 1996; Dudas, 1987), as metals are known to sorb strongly to these soil materials. Other soil properties that affect bioavailability and hence toxicity include particle interactions, percent organic carbon, $\mathrm{pH}$, redox, cation exchange capacity, percent clay and the time since the metal/metalloid was added (aging) (Ruby et al., 1999; NRC, 2003; McLaughlin, 2005; Kuperman et al., 2006; USEPA, 2007a; Smolders et al., 2009).

In sediment, some key factors affecting bioavailability include aging, acid volatile sulphide content, redox and iron/manganese oxide content (NRC, 2003; USEPA, 2007a). Iron and manganese undergo both oxidation and reduction reactions depending on soil/sediment conditions. This has important implications for both bioavailability and toxicity, since both (iron) $\mathrm{Fe}^{3+}$ and (manganese) $\mathrm{Mn}^{4+}$ ions are major structural metals, and thus chemical reduction of these cations affects the amount of mineral surfaces available for binding (and thus retaining) other metals (McLaughlin, 2005), as previously noted. Typically for metal cations, as $\mathrm{pH}$ increases (alkaline conditions) bioavailability/solubility and toxicity decrease as a result of increased negative charges and a tendency toward the formation of sparingly soluble compounds (phosphates, carbonates, hydroxides). Under reducing conditions, many metals (soil, sediment) form insoluble sulphide compounds, thereby reducing their bioavailability (McLaughlin, 2005; USEPA 2007a).

The physical form of the metal/metalloid also affects bioavailability. For example, lead and arsenic occur in soil as a complex mixture of solid-phase chemical compounds of varying particle sizes and morphologies. These compounds include discrete mineral phases, co-precipitated and adsorbed species associated with soil minerals or organic matter and dissolved species that may be complexed by a variety of organic/inorganic ligands (Ruby et al., 1999). Metals/metalloids contained within mineral matrices and also as slag are also known to have relatively low bioavailability. For example, the relative bioavailability of lead to juvenile swine fed slag from a slag site in Utah was around 20\% (USEPA, 1998) of soluble lead acetate. Often the lead in slag at mining and smelting sites can be encapsulated within the soil mineral grains such as quartz, which will limit bioavailability (Ruby et al., 1999). The latter illustrates that not all forms of metals are readily absorbed into an organism.

In soil, leaching and aging of metals typically results in transformations to more stable forms and species, such that as the time from initial contamination increases, concomitant reductions in bioavailability (and toxicity) are apparent (USEPA, 2007a; Donner et al., 2012). For example, the toxicity of metals in solutions freshly added (or spiked) into soil have been shown to vary considerably from the toxicity associated with metal forms from aged, field-contaminated soils (Smolders et al., 2009). Smolders and colleagues believe this change in speciation (chemical form) may explain the poor relationship between total metal concentrations and toxicity observed across a wide range of biota. Leaching (aging) of soils has been shown to result in reductions of cationic metal toxicity to a variety of organisms (e.g., Smolders et al., 2004).

\subsection{Freshwater}

A number of countries are incorporating bioavailability in their environmental management approaches to freshwater contamination and compliance, such as the United Kingdom's use of the Biotic Ligand Model to implement environmental quality standards for metals under the Water Framework Directive (UK Environment Agency, 2009), which, like the United States (USEPA, 2007d), utilises the BLM for establishing site-specific metal compliance for aquatic ecological protection. The BLM is a mechanistic model (tool) that is used on a site-specific basis to quantitatively evaluate site water chemistry and its effects on metal speciation and bioavailability (Paquin et al., 2002). Key water chemistry parameters that control metal bioavailability from water include $\mathrm{pH}$, temperature, dissolved organic carbon (a measure of natural organic matter), major metal cations (i.e., calcium, magnesium, sodium and potassium), anions (i.e., sulphate, chloride) and dissolved inorganic carbon (i.e., carbon dioxide, carbonic acid, bicarbonate anion and 
carbonate). The use of these water chemistry parameters in establishing site-specific bioavailability is an improvement over consideration of hardness only, since water quality criteria based on hardness alone may be under-protective at low $\mathrm{pH}$ and over-protective at high dissolved organic carbon levels, as is the case with copper (USEPA, 2008) and because other water chemistry factors, identified above, have been shown by researchers to affect metal toxicity.

\section{$5 \quad$ Bioavailability: impact on site outcomes}

Although the more common bioavailability measures, as previously discussed, are frequently used in site risk assessments, the use of bioaccessibility to affect site outcomes for human health is not as common. Some illustrative examples of the successful use of bioaccessibility testing to support human health risk assessment and site cleanup are discussed in this section. Site examples illustrating similar concepts for ecological protection (e.g., use of BLM, bioavailability adjusted PNECs) are also available but are not reviewed here.

The National Zinc Corporation operated a smelter at Bartlesville, Oklahoma, a Superfund site, for 70 years without emission controls, resulting in downwind deposits of metals in various locations in Bartlesville. Lead and cadmium concentrations in the top $60 \mathrm{~cm}$ of soil were over three times the regional background levels for these metals (USEPA, 1993) and higher in some locations. House dust, soil and slag were all tested, using a combination of live animal feeding studies (lead, cadmium) and an arsenic bioaccessibility study (PTI Environmental Services, 1994). Following the site investigation, risk-based cleanup levels were developed that included bioavailability adjustments for arsenic, cadmium and lead. Based on the bioavailability test results for these, the relative bioavailability for each metal/metalloid used in the risk assessment was, respectively, 25\%, 33\% and 20\%. Using these adjustments for bioavailability, the USEPA and Oklahoma Department of Environmental Quality accepted a tripling in state cleanup levels for arsenic and cadmium (from 20 to $60 \mathrm{ppm}$ for arsenic and from 30 to $100 \mathrm{ppm}$ for cadmium) and an almost doubling in the cleanup level for lead (from 500 to 925 ppm) (USEPA, 1994). Incorporating the bioavailability adjustments resulted in remediation costs that were reduced by over US\$ 40 million; the bioavailability and bioaccessibility studies (including planning and execution) cost $0.5 \%$ of this amount.

In the United States, the California Department of Toxic Substances Control recently was awarded a grant by the USEPA to study the relative bioavailability of arsenic at the historical Empire Mine Site. The goal of the grant study was stated as follows:

"Through implementing the Study DTSC hopes to provide better tools for characterizing AML sites so that bioavailability of arsenic can be employed in risk assessment and risk management decisions, resulting in more cost-effective cleanups" (DTSC, 2013).

Though ongoing, bioaccessibility test results from one of the site arsenic samples tested using the PBET are instructive in illuminating that the arsenic present at the site has very low bioavailability (Mitchell et al., 2010), and thus a higher risk-based cleanup level for arsenic seems reasonable to expect:

- In-vitro gastric bioaccessibility of arsenic was reported as only $1.62 \%$.

- Most of the arsenic in the sample was associated with ferrihydrite mineral (iron mineral); iron oxides, as discussed in section 4.1, are known to lower arsenic bioavailability.

In New Zealand, soil protection standards prohibit the use of bioaccessibility testing in site-specific assessments (NZ Ministry for the Environment, 2011). The Thames Coromandel District Council, overseeing the site-specific health risk assessment of a very large residential subdivision built on historical mine tailings rich in arsenic, supported the use of bioaccessibility testing for the large area, given the potentially high surface fill removal volumes and/or capping cost liabilities they faced since significant areas with risk were identified based upon the Ministry's conservative arsenic soil cleanup standard, which incorporated a default $100 \%$ arsenic bioavailability. The average oral bioavailability of arsenic in surface and shallow soils based on dozens of samples taken across the subdivision soils was $27 \%$ (no arsenic mineral phase data available) (Golder Associates, 2012). The site-specific human health risk assessment conducted for the area 
found very low human health risk (Golder Associates, 2012). Using the site-specific bioaccessibility data, the default Ministry arsenic soil cleanup standard more than doubled from $20 \mathrm{mg} / \mathrm{kg}$ to $50 \mathrm{mg} / \mathrm{kg}$.

This was the first use of bioaccessibility testing in a contaminated land assessment in New Zealand. Acceptance of the results by the Ministry of Environment and the Thames Coromandel District Council was also in part due to the recent (December 2012) USEPA validation study conducted for arsenic, as previously discussed (Griffin and Lowney, 2012), which showed good correlations between arsenic PBETs (bioaccessibility) and live animal bioavailability feeding studies. Based on the results of the site risk assessment, the Thames Coromandel District Council recommended at an April 2013 meeting not to undertake physical remediation at the subdivision because of the very low risk to human health (Thames Coromandel District Council, 2013). Though no figures are currently available on the remedial cost savings resulting from the use of relative bioavailability in evaluating (the lowered) site exposure, they are substantial (millions of dollars).

\section{Conclusions}

This paper discusses why and under what conditions considering bioavailability for metals and metalloids is appropriate; these principles are also relevant to organic contaminants. A review of the history and use of bioavailability covered the most common bioavailability methods used and how bioaccessibility for soil ingestion exposure pathways (a typical driving pathway at contaminated sites), in particular, is a useful tool when assessing risk and remediation with regard to human health. An overview of important fate processes affecting bioavailability for metals and metalloids is instructive and provides insight for risk practitioners into physical and chemical parameters that, on a site-specific basis, will affect the bioavailability to receptors (human, ecological) from site exposure media. Finally, human health-based examples are provided of how bioavailability (specifically bioaccessibility) has historically been, and is currently being, used to maximise environmental relevance in the evaluation of site human health risk and remediation in order to achieve balance between health protection and sensible environmental remediation.

\section{References}

Alexander, M., Cunningham, S.D., Chaney, R.R., Huges, J.B. and Harmsen, J. (1998) Chemical measures of bioavailability, in Contaminated Soils: From Soil-Chemical Interactions to Ecosystem Management, R.P. Lanno (ed), Society of Toxicology and Chemistry Press, $445 \mathrm{p}$.

Casteel, S.W., Cowart, R.P., Weis, C.P., Henningsen, G.M., Hoffman, E., Brattin, W.J., Guzman, R.E., Starost, M.F., Payne, J.T., Stockham, S.L., Becker, S.V., Drexler, J.W. and Turk, J.R. (1997) Bioavailability of Lead to Juvenile Swine Dosed with Soil from the Smuggler Mountain NPL Site of Aspen, Colorado, viewed 15 April 2013 http://www.epa.gov/region8/r8risk/pdf/r8 asrba1997.pdf.

Davis, A., Ruby, M.V., Bloom, M., Schoof, R., Freeman, G. and Bergstrom, P.D. (1996) Mineralogic constraints on the bioavailability of arsenic in smelter impacted soils, Environmental Science and Technology, Vol. 30, pp. 392-399.

DTSC (California Department of Toxic Substances Control) (2013) Arsenic Relative Bioavailability Study, viewed 25 April 2013 , http://www.dtsc.ca.gov/InformationResources/Arsenic_Relative_Study.cfm

Donner, E., McLaughlin, M.J., Hodson, M.E., Heemsbergen, D., Warne, M.S., Nortcliff, S. and Broos, K. (2012) Ageing of zinc in highly-weathered iron-rich soils, Plant and Soil, Vol. 361, pp. 83-95.

Drexler, J.W. and Brattin, W.J. (2007) An in vitro procedure for estimation of lead relative bioavailability: with validation, Human and Ecological Risk Assessment, Vol. 13, pp. 383-401.

Dudas, M.J. (1987) Accumulation of native arsenic in acid sulphate soils in Alberta, Canadian Journal of Soil Sciences, Vol. 67, pp. 317-331.

Freeman, G.B., Schoof, R.A., Ruby, M.V., Davis, A.O., Dill, J.A., Liao, S.C., Lapin, C.A. and Bergstrom, P.D. (1995) Bioavailability of arsenic in soil and house dust impacted by smelter activities following oral administration in Cynomolgus monkeys, Fundamental and Applied Toxicology, Vol. 28, pp. 215-222.

Griffin, S. and Lowney, Y. (2012) Validation of an in vitro Bioaccessibility Test Method for Estimation of Bioavailability of Arsenic from Soil and Sediment, prepared by USEPA Region 8 and Exponent Inc. for the Environmental Security Technology Certification Program (ESTCP), Arlington, Va., ESTCP Project ER-200916, 30 p.

Golder Associates (2012) Moanataiari Subdivision, Thames Contaminated Land Health Risk Assessment, Thames Coromandel District Council, viewed 25 April 2013, http://www.tcdc.govt.nz/Your-Council/Council-Projects/CompletedProjects/Moanataiari-Project-Phases-1---3/Phase-3-Health-Risk-Assessment.

Kim, J.Y., Davis, A.P. and Kim, K.W. (2003) Stabilization of available arsenic in highly contaminated mine tailings using iron Environmental Science and Technology, Vol. 37, pp. 189-195. 
Kuperman, R.G., Checkai, R.T., Simini, M., Philips, C.T., Speicher, J.A. and Barclift, D.J. (2006) Toxicity benchmarks for antimony, barium, and beryllium determined using reproduction endpoints for Folsomia candida, Eisenia fetida, and Enchtraeus crypticus, Environmental Toxicology and Chemistry, Vol. 25, pp. 754-762.

Langmuir, D., Chrostowski, P., Chaney, R. and Vigneault, B. (2003) Issue paper on the environmental chemistry of metals, USEPA Risk Assessment Forum: Papers Addressing Scientific Issues in the Risk Assessment of Metals, Office of the Science Advisor, 107 p., viewed 2 February 2013, http://www.epa.gov/raf/publications/pdfs/ENVCHEMFINAL81904CORR01-25-05.pdf.

Malagelada, J.R., Longstreth, G.F., Summerskill, W.H.J. and Go, V.L.W. (1976) Measurement of gastric functions during digestion of ordinary solid meals in man, Gastroenterology, Vol. 70, pp. 203-210.

Malagelada, J.R., Robertson, J.S., Brown, M.L., Remington, M., Duenes, J.A., Thomfode, G.M. and Carryer, P.W. (1984) Intestinal transit of solid and liquid components of a meal in health, Gastroenterology, Vol. 87, pp. 1,255-1,263.

Meunier, L., Walker, S.R., Wragg, S.R., Parsons, M.B., Koch, I., Jamieson, H.E. and Reimer, K.J. (2010) Effects of soil composition on the bioaccessibility of arsenic from tailings and soil in Gold Mine Districts of Nova Scotia, Environmental Science and Technology, Vol. 44, pp. 2,667-2,674.

McLaughlin, M.J. (2005) Heavy metals, in Encyclopedia of Soil Science, R. Lal (ed), 2nd edition, CRC Press, Boca Raton, Fla., 2,060 p.

Mitchell, V.L., Alpers, C.N., Basta, N.T., Berry, D.L., Christopher, J.P., Eberl, D.D., Kim, C.S., Fears, R.L., Foster, A.E., Myers P.A. and Parsons, B.M. (2010) Identifying Predictors for Bioavailability of Arsenic in Soil at Mining Sites, California Department of Toxic Substances Control, viewed 2 February 2013, http://www.dtsc.ca.gov/AssessingRisk/upload/HERD_Fly-SOT.pdf.

NRC (National Research Council) (2003) Bioavailability of Contaminants in Soils and Sediments: Processes, Tools, and Applications, Committee on Bioavailability of Contaminants in Soils and Sediments, National Academy Press, Washington, DC, 432 p.

NZ Ministry for the Environment (2011) Methodology for Deriving Standards for Contaminants in Soil to Protect Human Health, Ministry for the Environment, Wellington, $207 \mathrm{p}$.

Paquin, P.R., Gorsuch, J.W., Apte, S., Bailey, G.E., Bowles, K.C., Campbell, P.G.C., Delos, C.G., Di Toro, D.M., Dwyer, R.L., Galvez, F., Gensemer, R.W., Goss, G.G., Hogstrand, C., Janssen, C.R., McGeer, J.C., Naddy, R.B., Playle, R.C., Santore, R.C., Schneider, U., Stubblefield, W.A., Wood, C.M. and Wu, K.B. (2002) The biotic ligand model: a historical overview, Comparative Biochemistry and Physiology, Part C: Toxicology \& Pharmacology, Vol. 133, pp. 3-35.

PTI Environmental Services (1994) Volume I, Appendix N, Bioavailability Study Remedial Investigation Report, National Zinc Site, Remedial Investigation Feasibility Study, prepared for the City of Bartlesville, Ok., September 1994, $437 \mathrm{p}$.

Roberts, S.M., Weimar, W.R., Vinson, J.R.T., Munson, J.W. and Bergeron, R.J. (2002) Measurement of arsenic bioavailability in soil using a primate model, Toxicological Sciences, Vol. 67, pp. 303-310.

Roberts, S.M., Munson, J.W., Lowney, Y.W. and Ruby, M.V. (2006) Relative bioavailability of arsenic from contaminated soils measured in the Cynomolgus monkey, Toxicological Sciences, Vol. 95, pp. 281-288.

Ruby, M.V., Davis, A. Kempton, J.H., Drexler, J.W. and Bergstrom, P.D. (1992) Lead bioavailability: dissolution kinetics under simulated gastric conditions, Environmental Science and Technology, Vol. 26, pp. 1,242-1,248.

Ruby, M.V., Davis, A., Link, T.E., Schoof, R., Chaney, R.L., Freeman, G.B. and Bergstrom, P. (1993) Development of an in vitro screening test to evaluate the in vivo bioaccessibility of ingested mine-waste lead, Environmental Science and Technology, Vol. 27, pp. 2,870-2,877.

Ruby, M.V., David, A., Schoof, R., Eberle, S. and Sellstone, C.M. (1996) Estimation of lead and arsenic bioavailability using a physiologically based extraction test, Environmental Science and Technology, Vol. 30, pp. 422-430.

Ruby, M.V., Schoof, R., Brattin, W., Goldade, M., Post, G., Harnois, M., Mosby, D.E., Casteel, S.W., Berti, W., Carpenter, M., Edwards, D., Cragin, D. and Chappell, W. (1999) Advances in evaluating the oral bioavailability of inorganics in soil for use in human health risk assessment, Environmental Science and Technology, Vol. 33, pp. 3,697-3,705.

Schaider, L.A., Senn, D.B., Brabander, D.J., McCarthy, K.D. and Shine, J.P. (2007) Characterization of zinc, lead, and cadmium in mine waste: implications for transport, exposure, and bioavailability, Environmental Science and Technology, Vol. 41(11), pp. 4,164-4,171.

Smolders, E., Buekers, J., Oliver, I. and McLaughlin, M.J. (2004) Soil properties affecting toxicity of zinc to soil microbial properties in laboratory-spiked and field-contaminated soils, Environmental Science and Technology, Vol. 23(11), pp. 2,633-2,640.

Smolders, E., Oorts, K., Sprang, P.V., Schoeters, I., Janssen, C.R., McGrath, S.P. and McLaughlin, M.J. (2009) Toxicity of trace metals in soil as affected by soil type and aging after contamination: using calibrated bioavailability models to set ecological soil standards, Environmental Toxicology and Chemistry, Vol. 28, pp. 1,633-1,642.

Thames Coromandel District Council (2013) Moanataiari, Latest News \& Public Notices, Moanataiari LIM, viewed 25 April 2013, http://www.tcdc.govt.nz/Global/1_Your\%20Council/Documents\%20including\%20Bylaws,\%20Policies\%20and\%20Strategies /LIM\%20Exec\%20Summary.pdf.

UK Environment Agency (2005) Environment Agency's Science Update on the use of Bioaccessibility Testing in Risk Assessment of Land Contamination, Bristol, February 2005, viewed 15 April 2013, http://www.environmentagency.gov.uk/static/documents/2-science_update_1284046.pdf.

UK Environment Agency (2007) Environment Agency's Science Update 02 on the Use of Bioaccessibility Testing in Risk Assessment of Land Contamination, Bristol, viewed 15 April 2013, http://www.environment-agency.gov.uk/static/documents/3science_update_02_1793841.pdf.

UK Environment Agency (2008a) An Ecological Risk Assessment Framework for Contaminants in Soil, Science Report SC070009/SR1, Environment Agency, Bristol, September 2008, 48 p.

UK Environment Agency (2008b) Guidance on the Use of Bioassays in Ecological Risk Assessment, Science Report SC070009/SR2c, Environment Agency, Bristol, October 2008, 53 p. 
UK Environment Agency (2009) Using Biotic Ligand Models to Help Implement Environmental Quality Standards for Metals under the Water Framework Directive, Science Report - SC080021/SR7b, Bristol, 93 p.

USEPA (United States Environmental Protection Agency) (1993) National Priorities List for Uncontrolled Hazardous Waste Sites, Proposed Rule No. 14, Federal Register Notice, Vol. 58, 10 May 1993, pp. 27,507-27,514.

USEPA (United States Environmental Protection Agency) (1994) EPA Superfund Record of Decision: National Zinc Corp., OU 01, Bartlesville, OK, December 13, 1994, 73 p.

USEPA (United States Environmental Protection Agency) (1998) Bioavailability of Lead in a Slag Sample from the Midvale Slag NPL Site, Midvale, Utah, Phase II Swine Bioavailability Investigations, USEPA Region 8, Denver, Colo., 74 p.

USEPA (United States Environmental Protection Agency) (2007a) Framework for Metals Risk Assessment, USEPA Office of the Science Advisor, Risk Assessment Forum, Washington, D.C., EPA 120/R-07/001, 172 p.

USEPA (United States Environmental Protection Agency) (2007b) Guidance for Evaluating the Bioavailability of Metals in Soils for Use in Human Health Risk Assessment, Office of Solid Waste and Emergency Response Directive 9285.7-80, Washington, D.C., $18 \mathrm{p}$.

USEPA (United States Environmental Protection Agency) (2007c) Proceedings: ISEA Bioavailability Symposium: Use of In Vitro Bioaccessibility/Relative Bioavailability Estimates for Metals in Regulatory Settings: What is Needed, Technical Workgroup Bioavailability Committee, October 2007, $101 \mathrm{p}$.

USEPA (United States Environmental Protection Agency) (2007d) Aquatic Life Ambient Freshwater Quality Criteria - Copper, USEPA Office of Water, Washington D.C., EPA-822-R-07-001, 204 p.

USEPA (United States Environmental Protection Agency) (2008) An Introduction to the Biotic Ligand Model, Standards Academy, USEPA, Washington, D.C., viewed 2 February 2013, http://water.epa.gov/learn/training/standardsacademy/upload/ 2008_08_20_standards_academy_special_blm_presentation-notes.pdf.

USEPA (United States Environmental Protection Agency) (2009) Validation Assessment of In Vitro Bioaccessibility Assay for Predicting Relative Bioavailability of Lead in Soils and Soil-like Materials at Superfund Sites, USEPA Office of Solid Waste and Emergency Response, Washington D.C., OSWER Directive 9200.3-51, 14 p. 